\title{
EVALUATION OF THE CHANGES IN THE COST FACTORS OF SUNFLOWER PRODUCED IN THRACE ON THE BASIS OF THE PROVINCES IN THE RESEARCH FIELD AND OF THE SIZES OF ENTERPRISE
}

\author{
Semerci, A. ${ }^{*}$, Kaya, Y. ${ }^{1}$, Sahin, I. ${ }^{2}$, Citak, N. ${ }^{2}$ \\ ${ }^{1}$ Trakya Agricultural Research Institute, 22100, Edirne, Turkey \\ ${ }^{2}$ Trakya Birlik, Edirne, Turkey
}

Received: January 3, 2011 Accepted: May 25, 2011

\section{SUMMARY}

In Turkey, which ranks the tenth country worldwide in the sunflower (Helianthus annuus L.) production, 60\% of the production is carried out in the Thrace region. Therefore agricultural enterprises in Thrace, situated in the European part of Turkey, have become masters in producing sunflower, and have become the centre of vegetable oil industry in the region owing to the produced raw material.

In this study, we aim to investigate the yield and income of the enterprises producing sunflower in Thrace Region in Turkey, as well as to discover whether the factors affecting the production are different. In the final section of the study, cost analysis is explained in detail on the basis of the cities and sizes of sunflower production area.

The data used in this study were collected from 571 agricultural enterprises which were chosen to represent the whole Thrace region with the Stratified Random Sampling method.

At the end of the study, although the cities where the study was conducted have the same climate and production technologies, it is found that in addition to the income and yield obtained per unit area, the terms of land rent, pesticide, fertilizing and seed, which directly affect the cost, show differences among cities statistically.

Key words: sunflower, agricultural income, crop cost, difference analysis

* Corresponding author: Phone: + 9028423581812; Fax: + 902842358210; e-mail: arifsemerci69@gmail.com 


\section{INTRODUCTION}

Vegetable oils are one of the main sources of energy necessary for human nutrition. Today, oily seeds from which vegetable oils are obtained are produced to provide the calories that are necessary for human nutrition and also as raw material for bio-fuel.

With $37.5 \%$ of cultivation field of oily seeds and $32.13 \%$ of production amount, soybean takes the first place in the world. The other important oily seeds are palm, cotton, coconut, rape, peanut and sunflower. Sunflower is the most important plant in Turkey from the aspect of production quantity and cultivation of oily seeds. Turkey, which takes the $10^{\text {th }}$ place among the biggest sunflower producing countries in the world, has $2.04 \%$ of sunflower cultivation field and $2.56 \%$ of sunflower production (Anonymous, 2009a).

Oily seeds and vegetable oils are one of the most important groups of products which Turkey has deficit of and this deficit can only be met by means of import. Turkey's foreign trade in agricultural products was 24.5 billion US\$ in 2008. The amount of export on the total scale of foreign trade was 11.5 billion US\$ whereas the amount of import was 13 billion US\$. The import value of vegetable and animal oil, which increased 2 fold in 2008 compared to 2007, was 1,7 billion US\$ total, of which 1,5 billion US\$ was vegetable oils import. When oily seeds are added to this number, the import of this group reached $23 \%$ of total agricultural products with 3 billion US\$ (Anonymous, 2009b).

Thrace has the most important and central position in sunflower production, which has the biggest proportion in the production of oily seeds in Turkey. Five cities constituting the Thrace region make up the $59.51 \%$ of cultivation fields of sunflower, $62.04 \%$ of production amount in Turkey (Anonymous, 2009c).

Sunflower plant, the most important product, replacing wheat in Thrace, is one of the most significant sources of income of the producers in the region. Due to the high proportion that it holds in the vegetable production, producers have become masters in producing sunflower so vegetable oil industry has developed in the region significantly.

In this research, some data used per unit area among the cities which are producing sunflower in Thrace were investigated together with the corresponding monetary amounts and tested whether there are differences statistically among the cities. Additionally, production costs in Turkey and other important countries where sunflower is produced are looked at in this study. In this context, cost of the sunflower is calculated according to the size of the production field in the investigated cities and the reasons of the differences are revealed. 


\section{MATERIAL AND METHODS}

\section{Material}

The primary data used in the research were obtained from the agricultural enterprises in Edirne, Kirkareli, Tekirdag and the other enterprises which are situated on the Thrace part of Istanbul and Canakkale. These enterprises were chosen by the Stratified Random Sampling method. The data which were used on the level of settlement were gathered from Provincial Directorate of Agriculture of the cities mentioned above and Ministry of Agriculture and Rural Affairs, General Directorate of Agricultural Production and Development. The lists of Supporting Premium of Sunflower for Oil of 2007 were used in order to collect data for cultivation fields of sunflower on the basis of individual farmers.

\section{Methods}

The research data depend on the project of "The Determination of Efficiency of Subsidizing Policies and Productivity in Sunflower Production" (TAGEM-08/AR-GE/ 06) which is supported by the Ministry of Agriculture and Rural Affairs. The formula for Stratified Random Sampling Method used in the research is given below (Yamane, 1967).

In the formula; $n=\frac{\Sigma(N h S h)^{2}}{N^{2} D^{2}+\Sigma N h(S h)^{2}}$

$\mathrm{n}$ : volume of sample

$\mathrm{N}_{\mathrm{h}}$ : unit number (frequency) in the layer of $\mathrm{h}$

$\mathrm{S}_{\mathrm{h}}$ : standard deviation in the layer of $\mathrm{h}$

$\mathrm{N}$ : the number of total units

D: $d / z$

$\mathrm{d}$ : the deviation of the average with a definite ratio $(1 \%-5 \%-10 \%$, etc.)

$z: \quad t-$ the value of the degree of unconstraint in the distribution chart (N-1) and a particular reliance limit (90\%-95\%-99\% etc).

In the scope of the research, 571 surveys have been conducted in the enterprises producing sunflower: 175 surveys in 16 villages from 9 districts in Edirne province, 116 surveys in 11 villages from 6 districts in Kirkareli province, 233 surveys in 21 villages from 9 districts in Tekirdag province, 26 surveys in 3 villages from 2 districts in Istanbul province, 21 surveys in 2 villages from 2 districts in Canakkale province.

These data gathered by means of survey are horizontal cross section data belonging to the production year of 2009. In determining settlements where the survey was conducted, $95 \%$ of reliance interval and $4 \%$ of deviation from average were considered. In determining the number of surveys conducted $95 \%$ of reliance interval and $1 \%$ of deviation from average were considered (Erkan and Cicek, 1996). 
Test of ANOVA determined whether there are differences from the point of factors affecting the cost of sunflower among cities where this survey was conducted. Turkey HSD test determined between which variables these differences occur (Ural and Kilic, 2006; Altunisik et al., 2007; Green et al., 2000). For this reason, multiple comparisons were made among the cities. Bottom and top limit values in $95 \%$ reliance interval, the importance level of differences and standard mistakes belonging to the used variable, were given in the charts of the multiple comparisons.

In the research, the cost of sunflower produced in the studied enterprises was calculated on the basis of both cities and sizes of enterprises. For this reason, the enterprises have been divided into 5 groups according to their size such as: 0.1-1.9 $\mathrm{ha}^{-1}, 2.0-4.9 \mathrm{ha}^{-1}, 5.0-9.9 \mathrm{ha}^{-1}, 10.0-19.9 \mathrm{ha}^{-1}$, and $>20 \mathrm{ha}^{-1}$. The criteria used in calculating the production cost of sunflower is given below with their formulas (Erkus and Demirci, 2007; Anonymous, 2009d; Perin et al., 1976).

- Total Gross Production Value (TGPV): Yield $\left(\mathrm{kg} / \mathrm{ha}^{-1}\right) \times$ Product Sale Price (including subsidizes)

- Net Profit (NP): TGPV - Variable Expenses+Constant Expenses

- Gross Profit (GP): TGPV - Variable Expenses

- Variable Expenses (VE): Soil Preparation + Planting + Fertilizing + Harvest + Transportation + Seed + Fertilizer + Chemicals

- Constant (Fixed) Expenses (CE): Land Rent + Other Expenses + Capital Interest + Administrative Expenses

- Other Expenses (OE): Total Cost (Variable Expenses + Constant Expenses) $\times 0.05$

- Capital Interest (CI): (Total Cost + Other Expenses + Land Rent) $\times($ Interest Rate of Production Period) $\times 0.07$

- Administrative Expenses (AE): (Total Cost + Other Expenses + Land Rent) $\times 0.03$

\section{RESULTS AND DISCUSSION}

\section{Diversity analysis concerning the costs of input used in unit area in sunflower production among the cities in research fields}

\section{Differences related to seed cost paid for unit area of sunflower}

According to the conducted variance analysis, it was determined that there is a $5 \%$ difference in statistically important level in terms of average seed cost (US\$/ha ${ }^{-1}$ ) per unit area among the cities (Table 1).

Table 1: General Variance analysis table belonging to sunflower seed cost among the cities

\begin{tabular}{lccccc}
\hline & Sum of Squares & $\begin{array}{c}\text { Degree of } \\
\text { Freedom }\end{array}$ & Mean Square & $\mathrm{F}$ & Sig. \\
\hline Between Groups & 88.502 & 4 & 22.126 & 2.896 & 0.022 \\
Within Groups & 4324.591 & 566 & 7.641 & & \\
Total & 4413.093 & 570 & & & \\
\hline
\end{tabular}


In the conducted survey, there is a 5\% difference in the importance level statistically among only the cities Canakkale-Istanbul-Kirkareli in the average seed cost among the cities (Table 2).

Table 2: Multiple comparative variance analysis table belonging to sunflower seed cost among the cities

\begin{tabular}{llccccc}
\hline \multirow{2}{*}{ (I) Provinces } & \multirow{2}{*}{ (J) Provinces } & $\begin{array}{c}\text { Mean } \\
\text { Difference }(\mathrm{I}-\mathrm{J})\end{array}$ & $\begin{array}{c}\text { Std. } \\
\text { Error }\end{array}$ & \multirow{2}{*}{ Sig. } & \multicolumn{2}{c}{$95 \%$ Confidence Interval } \\
\cline { 6 - 7 } Canakkale & Istanbul & $2.41143\left(^{\star}\right)$ & 0.81821 & 0.028 & 0.1723 & 4.6505 \\
& Kirkareli & $1.81929\left(^{\star}\right)$ & 0.65509 & 0.045 & 0.0266 & 3.6120 \\
\hline
\end{tabular}

* $\mathrm{P}<0.05$

The average sunflower seed costs in the cities are the following: Kirkareli 6.52 US\$/ha ${ }^{-1}$, Canakkale 6.69 US\$/ha ${ }^{-1}$, Tekirdag $6.69 \mathrm{US \$} / \mathrm{ha}^{-1}$, Edirne $6.88 \mathrm{US \$} / \mathrm{ha}^{-1}$ and Istanbul $7.74 \mathrm{US} \$ / \mathrm{ha}^{-1}$. In the research field, the average seed cost paid for sunflower types used in unit area is higher in Istanbul compared to the average of the other four cities. The main reason for this difference is the usage of the only IMI and genetically durable sunflower seeds in this city.

\section{Differences related to fertilizer cost paid for per unit area of sunflower}

According to the conducted variance analysis, it was determined that there is a $1 \%$ difference in statistically important level in the average fertilizer cost (US\$/ha ${ }^{-1}$ ) per unit area among the cities (Table 3).

Table 3: General variance analysis table belonging to sunflower fertilizer cost among the cities

\begin{tabular}{lccccc}
\hline & Sum of Squares & $\begin{array}{c}\text { Degree of } \\
\text { Freedom }\end{array}$ & Mean Square & F & Sig. \\
\hline Between Groups & 14119.583 & 4 & 3529.896 & 66.858 & .000 \\
Within Groups & 29883.184 & 566 & 52.797 & & \\
Total & 44002.767 & 570 & & & \\
\hline
\end{tabular}

In the conducted study, there is a $5 \%$ difference in the statistically important level among the cities concerning the average fertilizer cost except from CanakkaleIstanbul and Istanbul-Tekirdag (Table 4).

The average sunflower fertilizer costs in the cities used per unit area are like these: Edirne 5.09 US\$/ha ${ }^{-1}$, Kirkareli $9.37 \mathrm{US} / \mathrm{ha}^{-1}$, Tekirdag $12.14 \mathrm{US} \$ / \mathrm{ha}^{-1}$, Istanbul 13.38 US\$/ha ${ }^{-1}$ and Canakkale $16.09 \mathrm{US} \$ / \mathrm{ha}^{-1}$. These values (figures) show that the amount of the fertilizer cost paid for sunflower production in Canakkale is triple the amount in Edirne.

\section{Differences related to herbicide cost paid per unit area of sunflower}

According to the conducted variance analysis, it was determined that there is a $1 \%$ difference in importance level statistically in average herbicide cost (US\$/ha ${ }^{-1}$ ) per unit area among the cities (Table 5). 
Table 4: Multiple comparative variance analysis tables belonging to sunflower fertilizer cost used for unit area among the cities

\begin{tabular}{|c|c|c|c|c|c|c|}
\hline \multirow{2}{*}{ (I) Provinces } & \multirow{2}{*}{ (J) Provinces } & \multirow{2}{*}{$\begin{array}{l}\text { Mean Difference } \\
(I-J)\end{array}$} & \multirow{2}{*}{ Std. Error } & \multirow{2}{*}{ Sig. } & \multicolumn{2}{|c|}{ 95\% Confidence Interval } \\
\hline & & & & & Lower Bound & Upper Bound \\
\hline \multirow{4}{*}{ Canakkale } & Istanbul & 4.04762 & 2.15082 & 0.328 & -1.8383 & 9.9335 \\
\hline & Kirkareli & $10.04762\left({ }^{\star}\right)$ & 1.72204 & 0.000 & 5.3351 & 14.7601 \\
\hline & Edirne & $16.44190\left(^{*}\right)$ & 1.67805 & 0.000 & 11.8498 & 21.0340 \\
\hline & Tekirdag & $5.89311\left(^{*}\right)$ & 1.65552 & 0.004 & 1.3626 & 10.4236 \\
\hline \multirow{3}{*}{ Istanbul } & Kirkareli & $6.00000(*)$ & 1.60098 & 0.002 & 1.6188 & 10.3812 \\
\hline & Edirne & $12.39429\left(^{*}\right)$ & 1.55357 & 0.000 & 8.1428 & 16.6458 \\
\hline & Tekirdag & 1.84549 & 1.52921 & 0.747 & -2.3393 & 6.0303 \\
\hline \multirow{2}{*}{ Kirkareli } & Edirne & $6.39429\left(^{*}\right)$ & 0.86773 & 0.000 & 4.0197 & 8.7689 \\
\hline & Tekirdag & $-4.15451\left(^{*}\right)$ & 0.82332 & 0.000 & -6.4076 & -1.9014 \\
\hline Edirne & Tekirdag & $-10.54879\left(^{\star}\right)$ & 0.72684 & 0.000 & -12.5379 & -8.5597 \\
\hline
\end{tabular}

$\star P<0.01$

Table 5: General variance analysis table belonging to sunflower herbicide cost among the cities

\begin{tabular}{lccccc}
\hline & Sum of Squares & Degree of Freedom & Mean Square & $F$ & Sig. \\
\hline Between Groups & 503.782 & 4 & 125.945 & 17.593 & 0.000 \\
Within Groups & 4051.959 & 566 & 7.159 & & \\
Total & 4555.741 & 570 & & & \\
\hline
\end{tabular}

In the conducted study, there is a $5 \%$ difference in the statistically important level among the cities Canakkale-Istanbul-Kirkareli, Istanbul-Edirne-Tekirdag, Kirkareli-Edirne-Tekirdag in the average herbicide cost (Table 6).

Table 6: Multiple comparative variance analysis table belonging to sunflower herbicide cost used for per unit area among the cities

\begin{tabular}{|c|c|c|c|c|c|c|}
\hline \multirow{2}{*}{ (I) Provinces } & \multirow{2}{*}{ (J) Provinces } & \multirow{2}{*}{$\begin{array}{c}\text { Mean Difference } \\
(I-J)\end{array}$} & \multirow{2}{*}{$\begin{array}{l}\text { Std. } \\
\text { Error }\end{array}$} & \multirow{2}{*}{ Sig. } & \multicolumn{2}{|c|}{ 95\% Confidence Interval } \\
\hline & & & & & Lower Bound & Upper Bound \\
\hline \multirow{4}{*}{ Canakkale } & Istanbul & $-3.93905\left(^{*}\right)$ & 0.79200 & 0.000 & -6.1064 & -1.7717 \\
\hline & Kirkareli & $-3.33700\left(^{*}\right)$ & 0.63411 & 0.000 & -5.0723 & -1.6017 \\
\hline & Edirne & -1.64190 & 0.61791 & 0.062 & -3.3329 & 0.0491 \\
\hline & Tekirdag & -1.34866 & 0.60961 & 0.177 & -3.0169 & 0.3196 \\
\hline \multirow{3}{*}{ Istanbul } & Kirkareli & 0.60205 & 0.58953 & 0.846 & -1.0113 & 2.2154 \\
\hline & Edirne & $2.29714\left({ }^{*}\right)$ & 0.57207 & 0.001 & 0.7316 & 3.8627 \\
\hline & Tekirdag & $2.59039\left(^{*}\right)$ & 0.56310 & 0.000 & 1.0494 & 4.1314 \\
\hline \multirow{2}{*}{ Kirkareli } & Edirne & $1.69509\left(^{*}\right)$ & 0.31952 & 0.000 & 0.8207 & 2.5695 \\
\hline & Tekirdag & $1.98833(*)$ & 0.30317 & 0.000 & 1.1587 & 2.8180 \\
\hline Edirne & Tekirdag & 0.29324 & 0.26764 & 0.809 & -0.4392 & 1.0257 \\
\hline
\end{tabular}

* $\mathrm{P}<0.01$

The average sunflower herbicide costs of the cities used per unit area are as follows: Canakkale 0.25 US\$/ha ${ }^{-1}$, Tekirdag $1.16 \mathrm{US} / \mathrm{ha}^{-1}$, Edirne $1.35 \mathrm{US} \$ / \mathrm{ha}^{-1}$, 
Kirkareli 2.49 US\$ $/ \mathrm{ha}^{-1}$ and Istanbul $2.89 \mathrm{US} / \mathrm{ha}^{-1}$. The basic reason for the difference in herbicide cost per unit area is the usage of herbicides with different characteristics with respect to their durability to Orobanchaceae for seeds used in the production of sunflower. Unit prices of the herbicides used to fight with Orobanchaceae and weeds, accepted as one of the biggest problems especially in sunflower production, show a range between 4.01-5.358 US\$/1 and 43.49-53.53 US\$/1 in herbicide market. This situation may cause diversities in costs per unit area in sunflower production.

\section{Differences related to average land rent cost per unit area of sunflower}

According to the conducted variance analysis results, it was determined that there is a $1 \%$ difference in statistically important level in the aspect of average land rent cost (US\$ $/ \mathrm{ha}^{-1}$ ) per unit area among the cities (Table 7).

Table 7: Variance analysis table belonging to average land rent cost for per unit area of sunflower among the cities

\begin{tabular}{lccccc}
\hline & Sum of Squares & $\begin{array}{c}\text { Degree of } \\
\text { Freedom }\end{array}$ & Mean Square & F & Sig. \\
\hline Between Groups & 1786.733 & 4 & 446.683 & 4.289 & 0.002 \\
Within Groups & 58949.270 & 566 & 104.151 & & \\
Total & 60736.004 & 570 & & & \\
\hline
\end{tabular}

In respect of the conducted survey, there has been a $5 \%$ difference in the importance level statistically among Kirkareli-Edirne and Edirne-Tekirdag cities in the average land rent cost for average unit area among the cities (Table 8).

Table 8: Multiple comparative variance analysis table belonging to average land rent cost for per unit area of sunflower among the cities

\begin{tabular}{llccccc}
\hline (I) Provinces & (J) Provinces & $\begin{array}{c}\text { Mean Difference } \\
(\mathrm{I}-\mathrm{J})\end{array}$ & Std. Error & Sig. & \multicolumn{2}{c}{ 95\% Confidence Interval } \\
\cline { 6 - 7 } & & $3.51917\left(^{* \star}\right)$ & 1.21874 & 0.033 & 0.1840 & 6.8544 \\
\hline Kirkareli & Edirne & -0.28880 & 1.15636 & 0.999 & -3.4533 & 2.8757 \\
& Tekirdag & $-3.80797\left(^{\star}\right)$ & 1.02086 & 0.002 & -6.6016 & -1.0143 \\
\hline
\end{tabular}

${ }^{\star} \mathrm{P}<0.01,{ }^{* *} \mathrm{P}<0.05$

The average land rent costs of the cities for average unit area of sunflower are as follows: Edirne 25.27 US\$/ha ${ }^{-1}$, Istanbul 25.94 US\$/ha ${ }^{-1}$, Kirkareli 27.63 US\$/ ha $^{-1}$, Tekirdag 27.82 US\$/ha ${ }^{-1}$ and Canakkale 28.52 US\$/ha-1.

\section{ELEMENTS OF SUNFLOWER PRODUCTION COSTS}

According to the conducted survey it was determined that in the distribution of sunflower cost, land rent is $20.62 \%$, soil preparation is $30.80 \%$, input use is $7.19 \%$, care and harvest process $22.12 \%$ (Safak, 1981). In another research of the same area, it was determined that in the production of sunflower cost factors are distributed like these; soil preparation $30.97 \%$, care works $29.50 \%$, land rent $31.18 \%$ and the rest is the cost of harvest and thrashing $8.35 \%$ (Anonymous, 2001 ).

In this study, it was determined that the cost of land rent and the cost of soil cultivation form nearly half of the total production cost $(49.13 \%)$. The other cost 
Table 9: The cost of sunflower for the cities on research field (US\$/ha ${ }^{-1}$ )

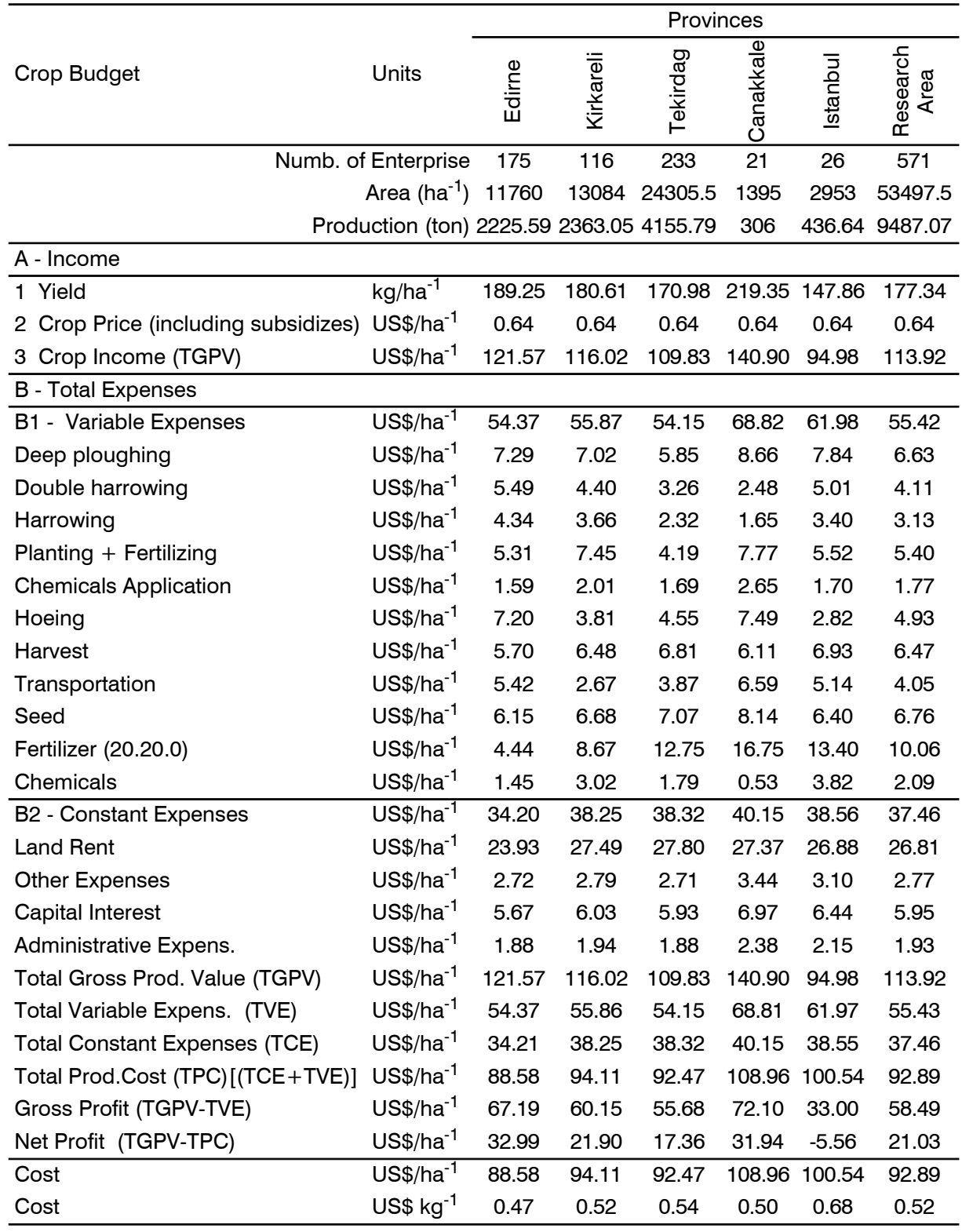


Table 10: The cost based on the size of sunflower planting area

\begin{tabular}{|c|c|c|c|c|c|c|}
\hline \multirow[b]{2}{*}{ Crop Budget } & \multirow[b]{2}{*}{ Units } & \multicolumn{5}{|c|}{ Sizes of Sunflower Planted Areas } \\
\hline & & $\begin{array}{c}1-19 \\
\left(\mathrm{ha}^{-1}\right)\end{array}$ & $\begin{array}{l}20-49 \\
\left(\mathrm{ha}^{-1}\right)\end{array}$ & $\begin{array}{l}50-99 \\
\left(\mathrm{ha}^{-1}\right)\end{array}$ & $\begin{array}{c}100-199 \\
\left(\mathrm{ha}^{-1}\right)\end{array}$ & $\begin{array}{l}200+ \\
\left(\mathrm{ha}^{-1}\right)\end{array}$ \\
\hline \multicolumn{2}{|c|}{ Numb. of Enterprise } & 45 & 155 & 191 & 131 & 49 \\
\hline \multicolumn{2}{|c|}{ Area $\left(h^{-1}\right)$} & 547.5 & 4988 & 12533 & 16865 & 18564 \\
\hline \multicolumn{2}{|c|}{ Production (ton) } & 100.49 & 927.21 & 2255.29 & 3064.89 & 3139.2 \\
\hline \multicolumn{7}{|l|}{ A.Income } \\
\hline \multirow{3}{*}{$\begin{array}{l}\text { 1.Yield } \\
\text { 2.Crop Price (including subsidizes) } \\
\text { 3.Crop Income (TGPV) }\end{array}$} & kg/ha-1 & 183.54 & 185.89 & 179.95 & 181.73 & 169.1 \\
\hline & US\$/ha ${ }^{-1}$ & 0.64 & 0.64 & 0.64 & 0.64 & 0.64 \\
\hline & US\$/ha-1 & 116.67 & 118.16 & 114.39 & 115.52 & 107.49 \\
\hline \multicolumn{7}{|l|}{ B.Total Expenses } \\
\hline \multicolumn{2}{|l|}{ B.1 Variable Expenses } & 56.10 & 58.97 & 57.11 & 58.25 & 56.09 \\
\hline Deep ploughing & US\$/ha ${ }^{-1}$ & 7.78 & 6.91 & 6.83 & 6.91 & 6.56 \\
\hline Double harrowing & US\$/ha-1 & 4.52 & 4.70 & 4.28 & 4.25 & 3.95 \\
\hline Harrowing & US\$/ha ${ }^{-1}$ & 3.09 & 3.75 & 3.18 & 3.19 & 3.15 \\
\hline Planting + Fertilizing & US\$/ha-1 & 4.80 & 5.11 & 5.00 & 5.06 & 4.56 \\
\hline Chemicals Application & US\$/ha ${ }^{-1}$ & 1.49 & 1.69 & 1.77 & 1.91 & 1.69 \\
\hline Hoeing & US\$/ha-1 & 4.90 & 7.39 & 5.92 & 6.75 & 5.02 \\
\hline Harvest & US\$/ha ${ }^{-1}$ & 6.46 & 6.59 & 6.59 & 6.48 & 6.54 \\
\hline Transportation & US\$/ha-1 & 4.92 & 4.84 & 4.77 & 4.70 & 4.70 \\
\hline Seed & US\$/ha ${ }^{-1}$ & 7.13 & 7.22 & 6.92 & 7.19 & 6.80 \\
\hline Fertilizer (20.20.0) & US\$/ha-1 & 9.20 & 9.17 & 10.16 & 9.80 & 10.51 \\
\hline Chemicals & US\$/ha-1 & 1.82 & 1.60 & 1.70 & 2.01 & 2.61 \\
\hline B2.Constant Expenses & US\$/ha ${ }^{-1}$ & 38.47 & 38.00 & 37.56 & 37.00 & 37.53 \\
\hline Land Rent & US\$/ha-1 & 27.93 & 27.30 & 27.01 & 26.42 & 27.05 \\
\hline Other Expenses & US\$/ha ${ }^{-1}$ & 2.64 & 2.64 & 2.64 & 2.64 & 2.64 \\
\hline Capital Interest & US\$/ha-1 & 6.07 & 6.22 & 6.08 & 6.11 & 6.00 \\
\hline Administrative Expenses & US\$/ha ${ }^{-1}$ & 1.84 & 1.84 & 1.84 & 1.84 & 1.84 \\
\hline Total Gross Production Value (TGPV) & US\$/ha-1 & 116.67 & 118.16 & 114.39 & 115.52 & 107.49 \\
\hline Total Variable Expenses (TVE) & US\$/ha ${ }^{-1}$ & 56.10 & 58.97 & 57.11 & 58.25 & 56.09 \\
\hline Total Constant Expenses (TCE) & US\$/ha-1 & 38.47 & 38.00 & 37.56 & 37.01 & 37.54 \\
\hline Total Prod.Cost (TPC) [(TCE+TVE)] & US\$/ha ${ }^{-1}$ & 94.57 & 96.97 & 94.67 & 95.26 & 93.62 \\
\hline Gross Profit (TGPV- TVE) & US\$/ha-1 & 60.57 & 59.19 & 57.28 & 57.27 & 51.41 \\
\hline Net Profit (TGPV-TPC) & US\$/ha ${ }^{-1}$ & 22.10 & 21.19 & 19.72 & 20.26 & 13.87 \\
\hline Cost & US $\$ / \mathrm{ha}^{-1}$ & 94.57 & 96.97 & 94.67 & 95.26 & 93.62 \\
\hline Cost & US\$ $/ \mathrm{kg}^{-1}$ & 0.52 & 0.52 & 0.53 & 0.52 & 0.55 \\
\hline
\end{tabular}


components are fertilization cost, harvesting cost, interest on capital and cost of planting.

\section{SUNFLOWER COST IN THE RESEARCH AREA}

\section{Sunflower cost in the cities on research field}

It was determined that average gross income obtained per unit area is 58.49 $\mathrm{US} \$ / \mathrm{ha}^{-1}$ and the average net income is $21.03 \mathrm{US} \$ / \mathrm{ha}^{-1}$. When the enterprises where this survey was conducted are compared, it is found that the highest gross and net income per unit area were obtained from enterprises producing sunflower in Edirne. Moreover, in this survey it is also shown that sunflower production in Istanbul is not a profitable activity for producers (Table 9).

\section{The cost based on the size of sunflower planting area}

While the highest gross income in per unit area in terms of sunflower planting area was obtained from the smallest enterprises group (0.1-1.9 ha-1), it is seen that as the size of the enterprises increases, the gross income obtained from them decreases. There is a similar situation with net income, obtained per unit area. As the size of enterprises increases, gross and net income decrease along with the decrease in yield value per unit area. Flexible high costs have an important role on increasing of cost (Table 10).

\section{CONCLUSION}

Thrace is one of the leading locations where the production of sunflower is intensely carried out. Thanks to its suitable climate conditions and modern agricultural methods, Thrace is not only the centre of sunflower production for Turkey but also for Europe. For this reason Thrace has a special position in sunflower production in Turkey.

In the agricultural enterprises in Thrace, sunflower planting area has $43 \%$ share in vegetable production and $20 \%$ share in agricultural income. Among the cities where the survey was conducted, there was a $5 \%$ difference in significance level statistically in terms of seed, fertilizer, chemicals and land rent which affect the cost of sunflower along with the income and yield obtained per unit area.

The cost of Turkey's sunflower production is about $80 \%$ higher than the cost of the top 5 countries in sunflower production (Russian Federation, Ukraine, Argentina, China and India). This fact causes vegetable oil industry, which is under research field, to turn towards importing. The main reason for this is the fact that the costs of importing is more reasonable compared with the high production cost in domestic markets.

When the cost of sunflower produced in research field is examined, it can be seen that land rent and soil cultivating cost constitute the biggest portion with a per- 
centage of $43.13 \%$. Average yield per unit area was determined as $177.34 \mathrm{~kg} \mathrm{ha}^{-1}$, gross income $59.49 \mathrm{US} \$ / \mathrm{ha}^{-1}$, net income $21.03 \mathrm{US} \$ / \mathrm{ha}^{-1}$ in research field. Contrary to general expectation, the highest gross income and net income were obtained from the smallest sized enterprises group. In the research it was observed that as the sunflower planting area increases, there is a decrease in yield and an increase in cost factors.

The production in Turkey is a highly expensive and less profitable branch of production when compared to other crops. The result of the research shows that the production of sunflower in Turkey, which is among the top 10 countries in world's sunflower production, is not profitable. To develop competitiveness in the world sunflower market, the cost components of sunflower should be reduced around the level of $200 \mathrm{USS}^{-1}$ by using various methods which are not contrary to the constantly changing and developing agribusiness dynamics and regulations. Moreover, input should be provided under more appropriate conditions in sunflower production.

In 2009, sunflower production in Turkey was below the production numbers of the year 1989. In Turkey, in order to meet the existing deficit in oil industry, firstly a parity model should be provided to the sunflower producer. This model should also be flexible and compatible with the profits of production per unit in areas where they compete or choose as an alternative other products.

Supporting of the products which are common in sunflower production areas should be abandoned partially and instead of them planting of sunflower should be encouraged. Although there is about 15 million ton wheat demand in Turkey, the production is between 19-21 million ton. In order to make Thrace completely an area of sunflower production, wheat production in this region could be excluded from subvention over time. To make this possible, income which is equivalent to wheat production income, should be guaranteed for sunflower producer in the area.

To meet the existing oil deficit in Turkey, first of all, seed which is high in oil should be used technically and irrigation should certainly be made available for production of sunflower. For this reason both works of R\&D should be supported in seed improvement and every kind of support should certainly be given for irrigation infrastructure.

To increase the production of oily seeds in general and sunflower in particular all around Turkey and to meet the demand, Production Of Oily Seeds and Foreign Trade Regime should be determined as Priority Areas and for this reason Oily Seeds Supporting Model should be put into practice with its own budget.

In this study, it is concluded that in order to meet the existing vegetable oil deficit in Turkey, specifically sunflower oil, it is not only necessary to make some technical changes (to support the usage of the genres high in oil, to increase the presence of irrigation, etc.), but also production of oily seeds in Agricultural Support System needs to be supported by establishing a different budget and decision mechanism. 


\section{REFERENCES}

Anonymous, 2001. Input use and production cost of some important crops in Turkey. MARA. Agricultural Economics Research Institute. Project No:2001-14, Ankara.

Anonymous, 2009a. FAO Agricultural Statistical Database. Available at: http//www.fao.org.

Anonymous, 2009b. Agriculture in Turkey with economical indicators. MARA. Agricultural Economics Research Institute. Project No: 176, Ankara. pp. 95.

Anonymous, 2009c. Databases Crop Production Statistics. Available at: http://www.turkstat.gov.tr.

Anonymous, 2009d. Costs of agricultural products in Thrace region. MARA. Kirkareli Atatürk Soil and Water Resources Research Institute. Kirkareli, pp. 5.

Altunisik, R., Coskun, R., Bayraktaroglu, S. and Yildirim, E., 2007. Research methods in social science (SPSS appl.). Sakarya Publ. Adapazari, pp. 281.

Erkan, O. and Cicek A., 1996. Research and sampling methods in agricultural economics. GOP Uni. Agr. Fac. Publ. Tokat, No: 12(6): 45.

Erkus, A. and Demirci, R., 2007. Agricultural administration and planning. Ankara Uni. Agr. Fac. Publ. Ankara, Turkey, No:1435: 31-39.

Green, S.B., Salkind, N.J. and Akey, T.M., 2000. Using SPSS for windows, analyzing and understanding data. Second Edition, Prentice-Hall, Inc., Upper Saddle River, New Jersey, USA, pp. 243-252.

Perin, R.K., Winkelman, D.L., Moscardi, E.R. and Anderson, J.R., 1976. Agronomik Verilerden Ekonomik Analize Gidiş. Yayin No: 27.CMMYT. Apardato Postal 6-641, Mexico 6 D.F. pp. 70-73.

Safak, A., 1981. Ayçiçeginin yogun olarak üretildigi Edirne, Bursa ve Tekirdag illerinde işletme düzeyinde üretim maliyetleri ve üretim tekniginin ekonomik yönden degerlendirilmesi ve pazarlamasi üzerine araştirma. MARA. GDAR. Tarim Ekonomisi Araştirmalari ve Egitimi Ülkesel Projesi', Uygulama Projesi Kod. No: 7-059/060-1/2-342, Bahçe Kültürleri Araştirma Enstitüsü Müdürlügü. Yalova, Istanbul, p. 73.

Ural, A. and Kilic, I., 2006. Scientific research process and data analysis with SPSS. Detay Publ. Ankara, No:113: 213-218.

Yamane, T., 1967. Elementary sampling theory. Prentice-Hall Inc. Englewood Cliffs, N. Jersey, USA. 